\title{
The effect of adenosine triphosphate on propofol-induced myopathy in rats: a biochemical and histopathological evaluation
}

\author{
Kezban Tuna Ozkaloglu Erdem ${ }^{1}$, Zehra Bedir ${ }^{2}$, Irem Ates ${ }^{3}$, Ufuk Kuyrukluyildiz ${ }^{4}$, Taha Abdulkadir Coban ${ }^{5}$, \\ Gulce Naz Yazici ${ }^{6}$, Yusuf Kemal Arslan ${ }^{7}$, Zeynep Suleyman ${ }^{8}$, and Halis Suleyman ${ }^{9 * *}$
}

${ }^{1}$ Balikesir Ataturk City Hospital Anesthesiology and Reanimation Clinic, Balikesir 10010, ${ }^{2}$ Department of Anesthesiology and Reanimation, Erzurum Nenehatun Maternity Hospital, Erzurum 25000, ${ }^{3}$ Department of Anesthesiology and Reanimation, Faculty of Medicine, Ataturk University, Erzurum 25000, Departments of ${ }^{4}$ Anesthesiology and Reanimation, ${ }^{5}$ Medical Biochemistry, ${ }^{6}$ Histology and Embryology, ${ }^{7}$ Biostatistics, Faculty of Medicine, Erzincan Binali Yildirim University, Erzincan $24100,{ }^{8}$ Department of Nursing, Faculty of Health Sciences, Erzincan Binali Yildirim University, ${ }^{9}$ Department of Pharmacology, Faculty of Medicine, Erzincan Binali Yildirim University, Erzincan 24100, Turkey

\section{ARTICLE INFO}

Received July 29,2020

Revised October 11, 2020

Accepted October 12, 2020

\section{*Correspondence}

Halis Suleyman

E-mail: halis.suleyman@gmail.com

Key Words

Adenosine triphosphate

Muscle

Myopathy

Propofol

Rat

Rhabdomyolysis
ABSTRACT Propofol infusion syndrome characterized by rhabdomyolysis, metabolic acidosis, kidney, and heart failure has been reported in long-term propofol use for sedation. It has been reported that intracellular adenosine triphosphate (ATP) is reduced in rhabdomyolysis. The study aims to investigate the protective effect of ATP against possible skeletal muscle damage of propofol in albino Wistar male rats biochemically and histopathologically. PA-50 $(n=6)$ and PA-100 $(n=6)$ groups of animals was injected intraperitoneally to $4 \mathrm{mg} / \mathrm{kg}$ ATP. An equal volume $(0.5 \mathrm{ml})$ of distilled water was administered intraperitoneally to the P-50, P-100, and HG groups. One hour after the administration of ATP and distilled water, $50 \mathrm{mg} / \mathrm{kg}$ propofol was injected intraperitoneally to the P-50 and PA-50 groups. This procedure was repeated once a day for 30 days. The dose of $100 \mathrm{mg} / \mathrm{kg}$ propofol was injected intraperitoneally to the P-100 and PA-100 groups. This procedure was performed three times with an interval of 1 days. Our experimental results showed that propofol increased serum CK, CK-MB, creatinine, BUN, TP I, ALT, AST levels, and muscle tissue MDA levels at $100 \mathrm{mg} / \mathrm{kg}$ compared to $50 \mathrm{mg} / \mathrm{kg}$ and decreased tGSH levels. At a dose of $100 \mathrm{mg} /$ $\mathrm{kg}$, propofol caused more severe histopathological damage compared to $50 \mathrm{mg} /$ $\mathrm{kg}$. It was found that ATP prevented propofol-induced muscle damage and organ dysfunction at a dose of $50 \mathrm{mg} / \mathrm{kg}$ at a higher level compared to $100 \mathrm{mg} / \mathrm{kg}$. ATP may be useful in the treatment of propofol-induced rhabdomyolysis and multiple organ damage.

\section{INTRODUCTION}

Propofol (2,6-diisopropylphenol) is a short-acting drug used in anesthesia induction and maintenance in short procedures and outpatient procedures [1]. When administered intravenously, it induces anesthesia at a rate similar to barbiturates, but postoperative recovery is much faster [2]. Propofol is one of the most preferred drugs in intensive care units because it is a strong anes- thetic and effective sedative [3,4]. However, multiple organs and system damage known as propofol infusion syndrome (PIS) have been reported in those using propofol for a long time for sedation [5]. Retrospective studies have shown that the risk of PIS is high in all patients receiving short-term infusions at high doses or long-term infusions at different doses [5]. The literature has revealed that PIS progresses with severe metabolic acidosis, rhabdomyolysis, kidney, and heart failure, and can even lead to death [6].

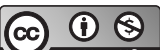

This is an Open Access article distributed under the terms of the Creative Commons Attribution Non-Commercial License, which permits unrestricted non-commercial use, distribution, and reproduction in any medium, provided the original work is properly cited. Copyright @ Korean J Physiol Pharmacol, pISSN 1226-4512, elSSN 2093-3827
Author contributions: K.T.O.E. and Z.B. contributed to conception, design, acquisition, analysis. I.A. and U.K. contributed to interpretation, and drafted the manuscript. T.A.C. and G.N.Y. contributed to histopathological examination and revised the manuscript. Y.K.A. contributed to data analysis, Z.S. and H.S. conducted the animal experiments, writing article, critically revised the manuscript, final approval. 
One of the causes of mortality, rhabdomyolysis is a serious muscle injury characterized by the breakdown of skeletal muscle cells. It has been reported that skeletal muscle and myocardial cell damage markers such as creatine kinase $(\mathrm{CK})$, creatine kinase $\mathrm{MB}$ (CK-MB), and troponin-I (TP I) levels are increased in PIS $[7,8]$. It has also been reported that markers of liver damage such as lactate dehydrogenase (LDH), aspartate aminotransferase (AST), alanine aminotransferase (ALT) are also increased in PIS [8]. It has been explained that one of the important clinical signs of PIS in literature is renal failure [9]. In histopathological examination, necrosis was observed in the renal tubules [10]. This event is followed by progressive increases in serum creatinine and blood urea nitrogen (BUN) concentrations [11]. Serum creatinine and BUN are used to evaluate oxidative kidney damage. The increase in creatinine and BUN has been associated with an increase in malondialdehyde (MDA), an oxidant parameter, and a decrease in endogenous antioxidant levels such as glutathione (GSH) [12]. A decrease in intracellular adenosine triphosphate (ATP) levels has been noted as the underlying cause of all forms of rhabdomyolysis [13]. Cray et al. [14] have shown that propofol has a destructive effect on the respiratory chain and leads to a decrease in ATP production [5]. An increase in myoplasmic $\mathrm{Ca}^{2+}$ concentration was detected in parallel with the decrease in intracellular ATP levels in rhabdomyolysis [13]. The increase of intracellular $\mathrm{Ca}^{2+}$ is caused by the decrease in ATP level due to ATPase inhibition [15]. It is known that increased intracellular $\mathrm{Ca}^{2+}$ ion concentration causes oxidative stress and leads to the initiation of pathological events in cells [16].

No data was found in the literature indicating oxidative stress in the pathogenesis of propofol-induced rhabdomyolysis. However, the pathophysiological process has been reported to include oxidative stress and inflammation in the glycerol-induced rhabdomyolysis (animal) model [17]. It has been noted that the damage caused by reactive oxygen species (ROS) such as hydrogen peroxide is associated with the loss of mitochondrial membrane potential and a decrease in ATP levels [18]. It has been reported that drugs increasing ATP levels restore mitochondrial damage and protect cells from ROS damage [19]. ATP to be examined in the present study for its possible protective effect against propofol-induced muscle damage is an organic compound involved in energy transformations in all living cells and contains carbon $(\mathrm{C})$, hydrogen $(\mathrm{H})$, oxygen $(\mathrm{O})$, nitrogen $(\mathrm{N})$ and phosphate $(\mathrm{P})$. More than $95 \%$ of the molecular oxygen is used by mitochondria for energy generation in the form of ATP [20]. The energy released from ATP degradation is the primary energy source for muscle contraction [21]. Kumbasar et al. [22] have highlighted that exogenous ATP protects ischemic tissue from oxidative stress by inhibiting the excessive production of oxidant markers such as xanthine oxidase and malondialdehyde and the consumption of antioxidant total glutathione. It is understood from the literature that rhabdomyolysis is a clinical condition of skeletal muscle destruction. Also, it shows that using the therapeutic dose for a long time or in high doses for a short time may lead to PIS. The aim of our study is to biochemical and histopathologically investigate the protective effect of ATP against possible skeletal muscle damage in rats treated with propofol at a therapeutic dose for a long time and at high doses for a short time.

\section{METHODS}

\section{Animals}

A total of 30 male albino Wistar rats weighing 245-257 grams were used in the experiment. The animals were obtained from Ataturk University Medical Experimental Application and Research Center. The animals were housed and fed in groups in normal laboratory conditions $\left(22^{\circ} \mathrm{C}\right)$ before the experiment. Animal experiments were performed by the National Guidelines for the Use and Care of Laboratory Animals and were approved by the local animal ethics committee of Ataturk University, Erzurum, Turkey (Ethics Committee [Dated: 28/10/2019, Meeting no:88012460-840.01-E50907]).

\section{Chemicals}

Propofol (1\%-20 ml ampoule) was obtained from Fresenius Kabi Pharmaceutical San-Turkey, thiopental sodium was provided by IE Ulagay-Turkey, and ATP was supplied by Zdorove Narodu Ukraine.

\section{Experimental groups}

Experimental animals were divided into five groups as healthy controls (HG), $50 \mathrm{mg} / \mathrm{kg}$ propofol (P-50), $50 \mathrm{mg} / \mathrm{kg}$ propofol +4 $\mathrm{mg} / \mathrm{kg}$ ATP (PA-50), $100 \mathrm{mg} / \mathrm{kg}$ propofol (P-100), and $100 \mathrm{mg} / \mathrm{kg}$ propofol + $4 \mathrm{mg} / \mathrm{kg}$ ATP (PA-100).

\section{Experimental procedure}

ATP was injected into the PA-50 $(n=6)$ group at a dose of 4 $\mathrm{mg} / \mathrm{kg}$ intraperitoneally (IP) to experiment. An equal volume (0.5 $\mathrm{ml})$ of distilled water was administered to the P-50 $(\mathrm{n}=6)$ and HG $(n=6)$ groups simultaneously. One hour after the administration of ATP and distilled water, $50 \mathrm{mg} / \mathrm{kg}$ propofol was injected IP to P-50 and PA-50 groups. This procedure was performed once a day for 30 days.

Furthermore, $4 \mathrm{mg} / \mathrm{kg}$ ATP was IP injected to the PA-100 (n = 6) group and an equal volume of distilled water was administered to the P-100 ( $\mathrm{n}=6)$ group. After one hour, $100 \mathrm{mg} / \mathrm{kg}$ propofol was intraperitoneally injected into both groups. This procedure was performed three times with an interval of 1 days. At the end of this period, CK, CK-MB, creatinine, BUN, TP I, AST, ALT, and $\mathrm{LDH}$ were measured in blood samples taken from all ani- 
mal groups. Also, MDA and total glutathione ( $\mathrm{tGSH}$ ) levels were measured in skeletal muscle tissue samples of animals killed by decapitation. Some of the skeletal muscle tissues were examined histopathologically. Biochemical and histopathological results obtained from all experimental groups were compared and evaluated.

\section{Biochemical analyses}

CK and CK-MB measurement: Analysis of plasma CK and CK-MB enzymes were measured using the commercial kit (11447378 122, Roche) in Cobas c701 system (Roche Molecular Diagnostics, Pleasanton, CA, USA).

BUN measurement: Quantitative determination of serum urea level was done by using the commercial kit (Cat. No. 10171778 122, Roche) in Cobas 8000 autoanalyzer by spectrophotometric method.

TP I assay: Troponin I (Troponin I kit - DRG Diagnostic) levels were measured in the ELISA device (ELISA reader ${ }^{\circledR}$-DAS) using a commercial kit (EIA-2952).

ALT and AST analysis: AST and ALT values were determined in cobas integra kit (ALT, 20764957322), (AST, 20764949322) as enzymatic.

LDH analysis: Serum LDH enzyme activity measurement was determined using the Cobas Integra kit (LDH, 03004732122).

Biochemical analysis of the muscle tissue: Homogenates were prepared from tissues for biochemical analysis on liver tissues. tGSH and MDA levels in the supernatants obtained from these homogenates were determined using appropriate methods in the literature.

Preparation of samples: At this stage of the study was weighed $0.2 \mathrm{~g}$ of each tissue sample removed. For MDA measurement, $1.15 \%$ potassium chloride solution was completed to $2 \mathrm{ml}$ in phosphate buffer $\mathrm{pH}=7.5$ for $\mathrm{tGSH}$ measurement and homogenized in ice medium. The tubes were then centrifuged at $+4^{\circ} \mathrm{C}$ at 10,000 rpm for $15 \mathrm{~min}$. Supernatants were used as the analysis sample.

MDA measurement: MDA measurement is based on the spectrophotometric measurement (at $532 \mathrm{~nm}$ ) of absorbance of a pink colored complex formed by thiobarbituric acid and MDA at high temperature $\left(95^{\circ} \mathrm{C}\right)[23]$.

tGSH measurement: DTNB (5,5'-Dithiobis [2-nitrobenzoic acid]) in the measurement medium is a disulfide chromogen and is readily reduced by compounds with sulfhydryl groups. The resulting yellow color was measured spectrophotometrically at 412 $\mathrm{nm}$ [24].

Histopathological examination: All of the tissue samples were first identified in a $10 \%$ formaldehyde solution for light microscope assessment. Following the identification process, tissue samples were washed under tap water in cassettes for $24 \mathrm{~h}$. Samples were then treated with a conventional grade of alcohol (70\%, 80\%, 90\%, and 100\%) to remove the water within tissues. Tissues were then passed through xylol and embedded in par- affin. Four-to-five micron sections were cut from the paraffin blocks and hematoxylin-eosin staining was administered. Their photos were taken following the Olympus DP2-SAL firmware program (Olympus Inc., Tokyo, Japan) assessment. Histopathological assessment was carried out by the pathologist blind for the study groups. The severity of histopathological findings in each section was scored between grade 0-3 (0-normal, 1- mild damage, 2-moderate damage, and 3-severe damage).

\section{Statistical analysis}

For statistical analysis IBM SPSS 22 was used (released 2013. IBM SPSS Statistics for Windows, Version 22.0; IBM Corp., Armonk, NY, USA). The results were presented as mean \pm standard deviation (SD). The distribution of variables was confirmed with the Shapiro-Wilk test. For biochemical measurements except CK-MB and Creatinine were compared with ANOVA. According to the homogeneity of variances, Tukey's HSD or Games-Howell tests were used as post-hoc test. For the comparisons of histopathological examinations, CK-MB and creatinine between groups Kruskal Wallis test was used with Dunn's test as a post-hoc test and adjusted $\mathrm{p}$ values were reported. A value of $\mathrm{p}$ less than 0.05 was considered significant for all tests.

\section{RESULTS}

\section{Biochemical findings}

CK, CK-MB, BUN, and TP I analysis results: As can be seen from Fig. 1, CK activity significantly increased in the blood serum of animals treated with $50 \mathrm{mg} / \mathrm{kg}$ propofol for one month compared to healthy and ATP-treated groups $(\mathrm{p}<0.001)$. Although the difference in CK activity between the $50 \mathrm{mg} / \mathrm{kg}$ propofol + ATP group and the healthy group was numerically close to each other, this difference was statistically significant $(\mathrm{p}<0.01)$. Besides, propofol administered at a dose of $100 \mathrm{mg} / \mathrm{kg}$ increased CK activity further compared to the $50 \mathrm{mg} / \mathrm{kg}$ propofol group and this difference was significant compared to the healthy and ATP group $(\mathrm{p}<0.0001)$. There was a significant difference in terms of $\mathrm{CK}$ activity between the propofol + ATP group and the healthy group ( $<<0.05)$.

Similarly, $50 \mathrm{mg} / \mathrm{kg}$ propofol increased CK-MB level compared to the healthy group $(\mathrm{p}=0.005)$ and the ATP group $(\mathrm{p}=0.02)$, while at $100 \mathrm{mg} / \mathrm{kg}$ the difference was even more compared to the healthy group $(\mathrm{p}<0.001)$ and the ATP group $(\mathrm{p}=0.014)$. No difference was found in CK-MB activity between the $50 \mathrm{mg} / \mathrm{kg}$ propofol + ATP group and the healthy group $(\mathrm{p}=0.25)$. Furthermore, there was no difference in CK-MB activity between the 100 $\mathrm{mg} / \mathrm{kg}$ propofol + ATP group and the healthy group $(\mathrm{p}=0.28)$.

Compared to the healthy group $(\mathrm{p}<0.001)$ and the ATP group $(\mathrm{p}<0.001), 50 \mathrm{mg} / \mathrm{kg}$ propofol administration increased BUN 

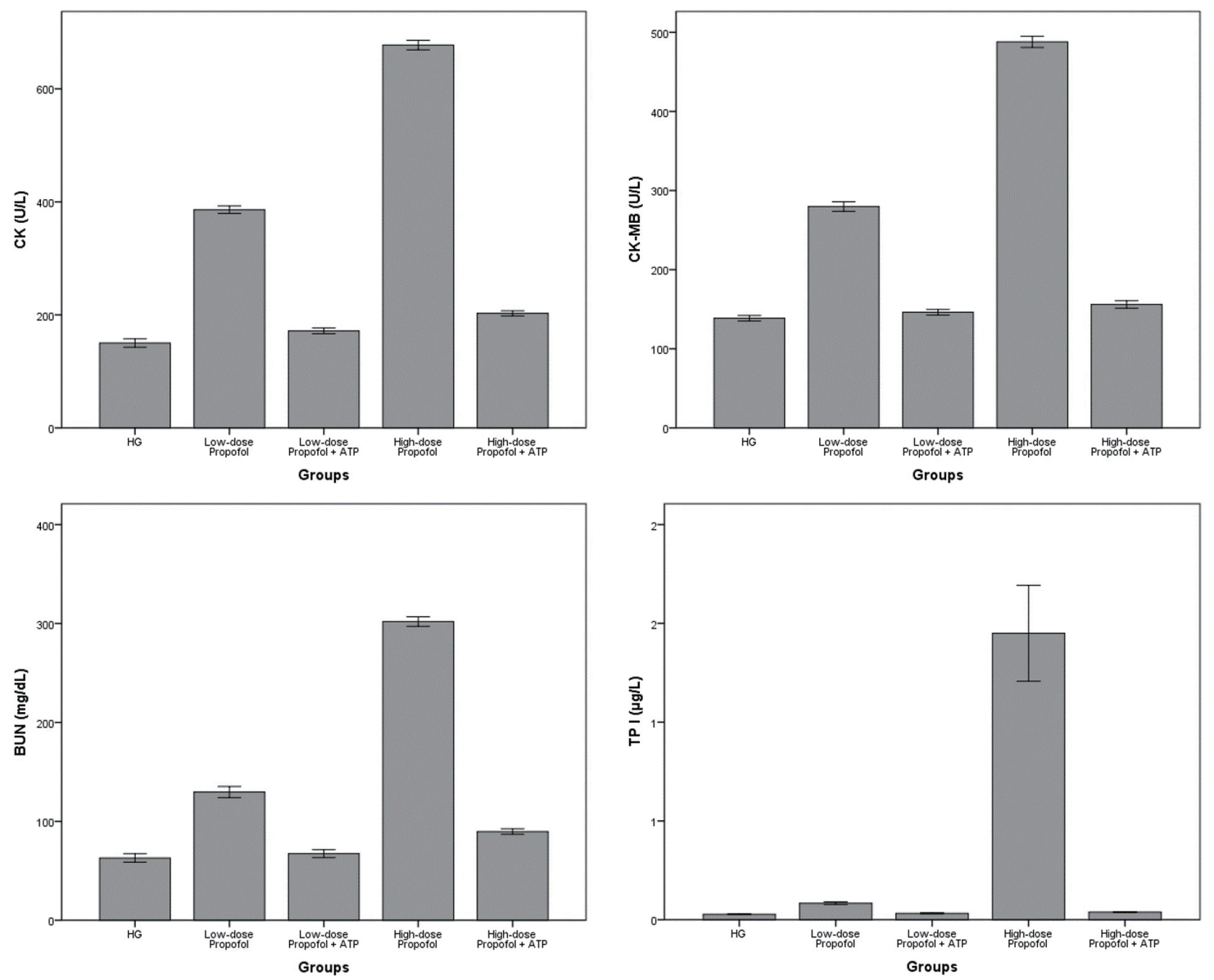

Fig. 1. CK, CK-MB, BUN, and TP I levels in the blood of the study groups. All groups were compared with HG ( $n=6)$. CK, creatine kinase; CK-MB, creatine kinase MB; BUN, blood urea nitrogen; TP I, troponin-I; ATP, adenosine triphosphate; HG, healthy controls.

level significantly. BUN level increased even more significantly by $100 \mathrm{mg} / \mathrm{kg}$ propofol administration compared to the healthy group $(\mathrm{p}<0.0001)$ and the ATP group $(\mathrm{p}<0.0001)$. The difference in the BUN level between the $50 \mathrm{mg} / \mathrm{kg}$ propofol + ATP group and the healthy group was statistically insignificant $(\mathrm{p}=$ 0.45). However, the difference in the BUN level between the 100 $\mathrm{mg} / \mathrm{kg}$ propofol + ATP group and the healthy group was statistically significant $(\mathrm{p}<0.001)$.

Also, $100 \mathrm{mg} / \mathrm{kg}$ propofol administration increased serum TPI levels of animals more significantly compared to the dose of $50 \mathrm{mg} / \mathrm{kg}(\mathrm{p}<0.001)$. The difference in TPI levels between the healthy group and $50 \mathrm{mg} / \mathrm{kg}$ propofol + ATP group was statistically insignificant $(\mathrm{p}=0.12)$. The difference in the TPI level between the $100 \mathrm{mg} / \mathrm{kg}$ propofol + ATP group and the healthy group was not found statistically significant ( $\mathrm{p}=0.07)$.

ALT, AST, and LDH analysis results: As can be seen from Fig. 2, ALT activity significantly increased in the blood serum of animals treated with $50 \mathrm{mg} / \mathrm{kg}$ propofol for one month compared to healthy and ATP-treated groups $(\mathrm{p}<0.001)$. Besides, propofol administered at a dose of $100 \mathrm{mg} / \mathrm{kg}$ increased ALT activity further compared to the $50 \mathrm{mg} / \mathrm{kg}$ propofol group and this difference was significant compared to the healthy and ATP groups $(\mathrm{p}<0.0001)$.
The difference in ALT activity between the healthy group and the $50 \mathrm{mg} / \mathrm{kg}$ propofol + ATP group was statistically insignificant ( $p>0.05$ ). The difference in ALT activity between the $100 \mathrm{mg} /$ $\mathrm{kg}$ propofol + ATP group and the healthy group was statistically significant $(\mathrm{p}<0.05)$.

Similarly, $100 \mathrm{mg} / \mathrm{kg}$ propofol administration increased AST activity further $(\mathrm{p}<0.001)$ compared to $50 \mathrm{mg} / \mathrm{kg}$ propofol administration. ATP significantly inhibited the propofol-related increase in AST activity at $50 \mathrm{mg} / \mathrm{kg}(\mathrm{p}<0.0001)$ and $100 \mathrm{mg} / \mathrm{kg}$ (p $<0.0001)$ doses. There was a significant difference in AST activity between the $50 \mathrm{mg} / \mathrm{kg}$ propofol + ATP group and the healthy group $(\mathrm{p}<0.05)$. A higher difference was observed in AST activity between the $100 \mathrm{mg} / \mathrm{kg}$ propofol + ATP group and the healthy group $(\mathrm{p}<0.01)$.

Propofol caused an increase in LDH activity in the blood serum of animals. $100 \mathrm{mg} / \mathrm{kg}$ propofol administration caused a higher increase in LDH activity compared to $50 \mathrm{mg} / \mathrm{kg}(\mathrm{p}<0.001)$. No difference was found between the $50 \mathrm{mg} / \mathrm{kg}$ propofol + ATP group and the healthy group $(\mathrm{p}=0.26)$. The difference between the $100 \mathrm{mg} / \mathrm{kg}$ propofol + ATP group and the healthy group was statistically significant $(\mathrm{p}=0.002)$.

MDA and tGSH analysis results: As shown in Fig. 3, the 

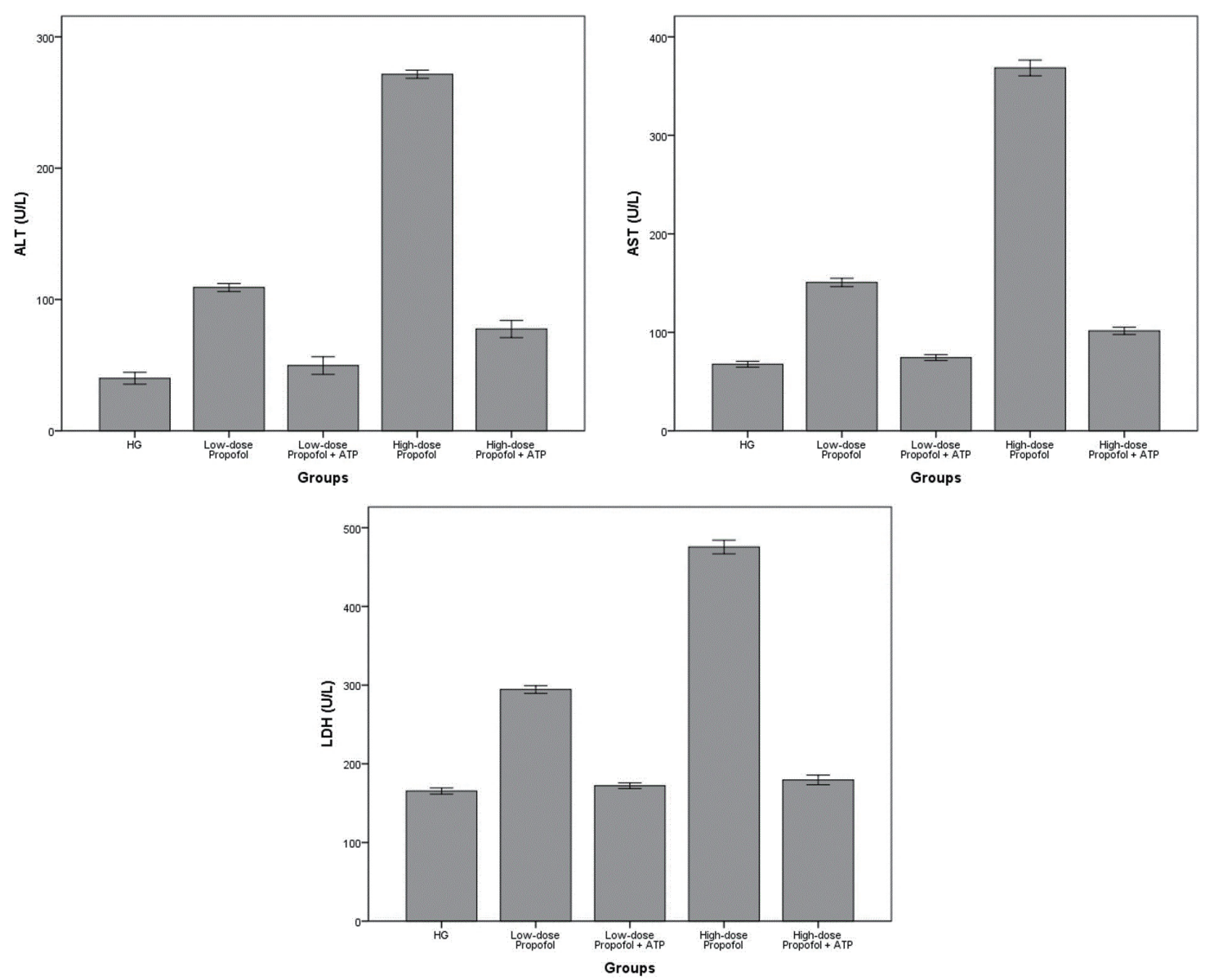

Fig. 2. ALT, AST, and LDH activity in the blood of the study groups. All groups were compared with HG $(n=6)$. ALT, alanine aminotransferase; AST, aspartate aminotransferase; LDH, lactate dehydrogenase; ATP, adenosine triphosphate; $\mathrm{HG}$, healthy controls.
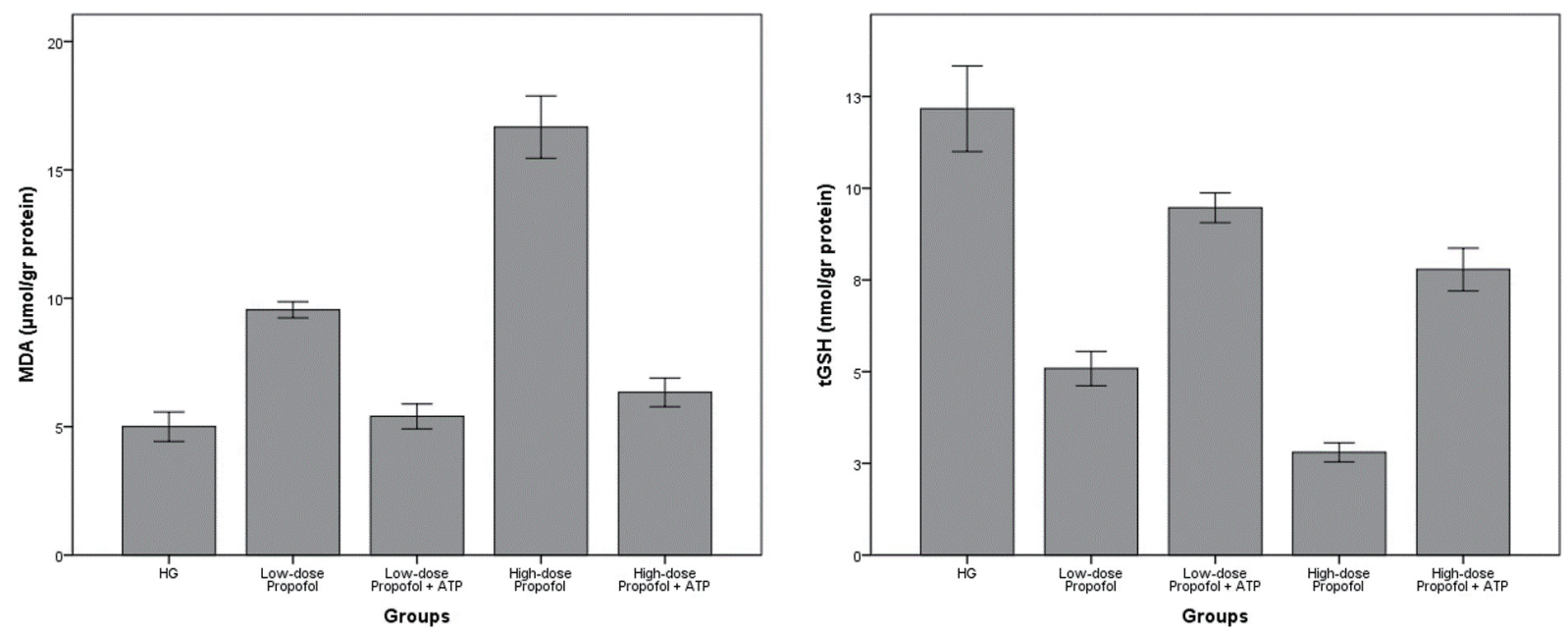

Fig. 3. MDA and tGSH levels in skeletal muscle tissue of the study groups. All groups were compared with $H G(n=6)$. MDA, malondialdehyde; tGSH, total glutathione; ATP, adenosine triphosphate; $\mathrm{HG}$, healthy controls.

amount of MDA in the muscle tissue of the animals treated with $50 \mathrm{mg} / \mathrm{kg}$ propofol for one month significantly increased compared to healthy and ATP-treated groups ( $\mathrm{p}<0.001)$. MDA level was higher in the $100 \mathrm{mg} / \mathrm{kg}$ propofol group compared to the $50 \mathrm{mg} / \mathrm{kg}$ propofol group $(\mathrm{p}<0.001)$. The difference in MDA amount in the muscle tissue of the healthy group and that of the $50 \mathrm{mg} / \mathrm{kg}$ propofol + ATP group was statistically insignificant $(\mathrm{p}$ $=0.69$ ). The difference in the MDA amount between the $100 \mathrm{mg} /$ 
$\mathrm{kg}$ propofol + ATP group and the healthy group was statistically significant $(\mathrm{p}<0.05)$.

The 50 and $100 \mathrm{mg} / \mathrm{kg}$ doses of propofol increasing MDA caused a decrease in tGSH in muscle tissue. Propofol further reduced the amount of tGSH at a dose of $100 \mathrm{mg} / \mathrm{kg}$ compared to 50 $\mathrm{mg} / \mathrm{kg}(\mathrm{p}<0.001)$. There was a significant difference between the amount of tGSH in the muscle tissue of the $50 \mathrm{mg} / \mathrm{kg}$ propofol + ATP group and the healthy group $(\mathrm{p}=0.009)$. This difference was more pronounced between the $100 \mathrm{mg} / \mathrm{kg}$ propofol + ATP group and the healthy group $(\mathrm{p}<0.001)$.

\section{Histopathological findings}

Normal muscle cell nuclei, muscle fibers, and blood vessels in the skeletal muscle tissue of the healthy animal group are shown in Fig. 4. In the $50 \mathrm{mg} / \mathrm{kg}$ propofol group, pale muscle fibers having a marked swelling and irregular appearance, conjunctive blood vessels, and polymorphonuclear cell infiltration were observed (Fig. 5A). Significant recovery and improvement were observed in the group treated with $50 \mathrm{mg} / \mathrm{kg}$ propofol + ATP. In this group, the muscle fibers were regularly aligned and their color was normal. The degenerative disruption in muscle fibers decreased and blood vessels were normal (Fig. 5B). Furthermore, irregularity in adjacent muscle fibers, degeneration coupled with disruptions in transverse lines of the muscle fibers, and some torn fibers were observed in the $100 \mathrm{mg} / \mathrm{kg}$ propofol group. When the overall tissue was evaluated, dilated and conjunctive blood vessels were observed and numerous polymorphonuclear cell infiltrations were seen around the blood vessels (Fig. 5C). In the $100 \mathrm{mg} /$ $\mathrm{kg}$ propofol + ATP group, muscle fiber nuclei and the alignment of muscle fibers showed normal appearance, mild confirmation in the blood vessels, and very few polymorphonuclear cells

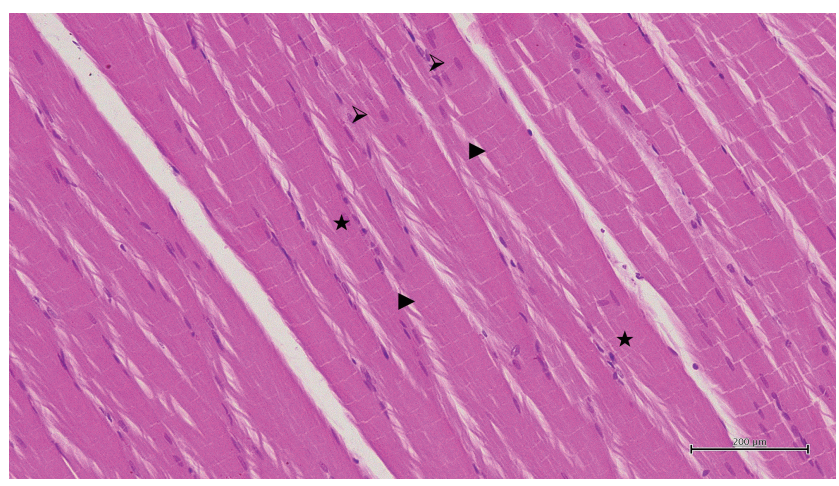

Fig. 4. Hematoxylin-eosin (H\&E) staining in skeletal muscle tissue in the healthy group. $>$, muscle cell nucleus; $\downarrow$, muscle fibers; $\star$, blood vessel $(\mathrm{H} \& \mathrm{E}, \times 200)$.

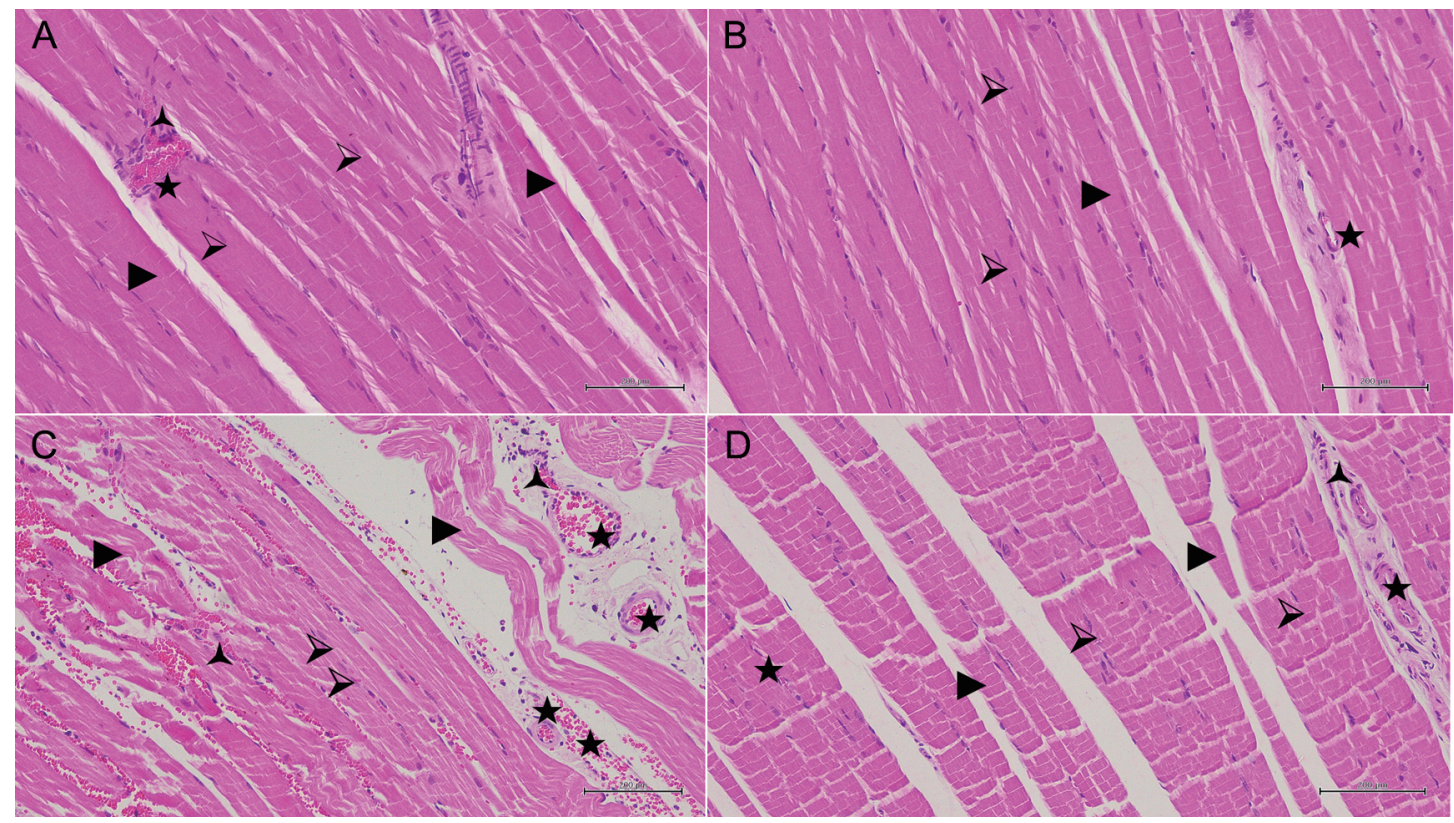

Fig. 5. Hematoxylin-eosin staining in skeletal muscle tissue in the low-dose (50 $\mathbf{m g} / \mathbf{k g}$ ) propofol group. (A) Hematoxylin-eosin (H\&E) staining

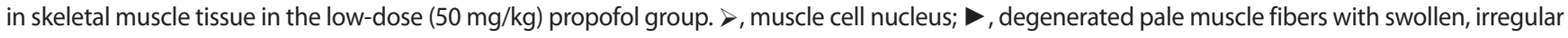
appearance; $\star$, congested blood vessel; $\curlywedge$, polymorphonuclear cell infiltration $(H \& E, \times 200)$. (B) H\&E staining in skeletal muscle tissue in the low-dose $(50 \mathrm{mg} / \mathrm{kg}$ ) propofol + ATP group. $>$, muscle cell nucleus; $\boldsymbol{\nabla}$, decreased degeneration in muscle fibers with regular color and alignment; $\star$, normal blood vessel $(H \& E, \times 200)$. (C) H\&E staining in skeletal muscle tissue in the high-dose (100 mg/kg) propofol group. $>$, disorganized and degenerated muscle cell nucleus; $\downarrow$, irregular, ruptured and degenerated muscle fibers; $\star$, congested and dilated blood vessel; $\curlywedge$, numerously polymorphonuclear cell infiltration (H\&E, $\times 200)$. (D) H\&E staining in skeletal muscle tissue in the high-dose $(100 \mathrm{mg} / \mathrm{kg})$ propofol + ATP group. $>$, normal muscle cell nucleus; $\boldsymbol{\nabla}$, mostly normal organized and decreased degeneration in muscle fibers; $\curlywedge$, the spot of polymorphonuclear cell infiltration; $\star$, mildly congested blood vessel $(\mathrm{H} \& \mathrm{E}, \times 200)$. 
around the vessels were observed (Fig. 5D).

\section{DISCUSSION}

In this study, the effect of ATP on the propofol administration at different doses, different intervals, and different durations was investigated biochemically and histopathologically. Our biochemical results showed that CK, CK-MB, TPI, ALT, AST, LDH, creatinine, and BUN levels were significantly higher in the blood serum of animals treated with $100 \mathrm{mg} / \mathrm{kg}$ propofol compared to 50 $\mathrm{mg} / \mathrm{kg}$. Besides, muscle MDA level was higher whereas tGSH was lower in the $100 \mathrm{mg} / \mathrm{kg}$ propofol group compared to $50 \mathrm{mg} / \mathrm{kg}$. Recent studies have reported that high-dose short-term propofol infusion causes PIS in patients. Furthermore, it has been reported that PIS develops in all patients undergoing long-term infusion at a low dose range [5]. CK enzymes are used in the clinics to determine whether there is any damage to the skeletal and cardiac muscle tissue of individuals [25]. In the literature, it is stated that an increase in CK is associated with the extent of muscle damage and the severity of the disease. Furthermore, it is emphasized that muscle cell damage is caused by CK leak from the cells into the blood serum [26]. Therefore, measuring serum CK activity is an important indicator of muscle cell necrosis and all types of muscular dystrophy [27]. Another important parameter used in the diagnosis of myocardial infarction and inflammatory skeletal muscle diseases is the CK-MB isoenzyme [28]. Chronic necrotic muscle injury can lead to an increase in CK-MB activity [29]. CK$\mathrm{MB}$ increases together with $\mathrm{CK}$ in patients with chronic kidney disease and destructive myopathies such as Duchenne muscular dystrophy, polymyositis, and dermatomyositis [30,31].

In our study, propofol increased the amount of serum TPI as well. In a previous study, it was reported that troponin increased in propofol-associated cardiac muscle damage [32]. TPI is known to be a highly sensitive parameter in myocardial damage [33]. Studies have suggested that the increase in TPI may be the result of a defect in the myocardia membrane caused by reactive oxygen products [34]. Propofol-associated ALT and AST elevations are multifactorial processes including skeletal muscle damage and hepatocellular damage [35]. Serum ALT and AST levels usually increase in rhabdomyolysis and these enzymes are produced by skeletal muscle. On the other hand, simultaneous liver disease has been shown to elevate the levels of these enzymes [36]. ALT is generally considered as a more specific marker for hepatocyte damage. However, there is also evidence for the production of ALT outside the liver [37]. AST is found in the liver, skeletal muscle, heart, kidneys, pancreas, and erythrocytes. Therefore, both hepatic inflammation and injury of another organ should be considered in the case of elevated serum AST levels [38]. Our experimental results are consistent with the results of the previous studies [36]. LHD, as well as ALT and AST levels, were elevated in animals treated with propofol. High LDH activity has been reported in skeletal muscle, heart, lung, liver, and kidney damage associated with propofol application [10]. In the study of El-Ganainy et al. [39], high levels of LDH were associated with cellular damage in muscle tissue. In another study, it has been emphasized that LDH increases in rhabdomyolysis and is associated with oxidative stress [40]. One of the important clinical symptoms of PIS is kidney failure [6]. The severe increase in BUN and creatinine levels shows that it is caused by permanent damage to kidney tubules [41]. It is stated that increases in serum BUN and creatinine concentrations are affected by nonrenal factors and are also indicators of excessive damage such as loss of functional nephrons [42]. Previous studies have also reported an excessive increase in BUN and creatinine levels in blood samples with high oxidant parameters [12]. Our experimental results show that animals treated with $100 \mathrm{mg} / \mathrm{kg}$ propofol have significantly higher MDA levels and lower tGSH levels in muscle tissue compared to $50 \mathrm{mg} / \mathrm{kg}$ propofol. This suggests that propofol shifts the oxidant-antioxidant balance in the muscle tissue in favor of oxidants. MDA is a cytotoxic product formed by peroxidation of cell membrane lipids with ROS. MDA leads to cellular damage by causing cross-linking and polymerization of membrane components [43]. However, they are neutralized by GSH and other enzymatic non-enzymatic antioxidant defense systems against overproduced ROS in healthy tissues [44]. To the best of our knowledge, no data is indicating oxidative stress in the pathogenesis of propofol-induced muscle damage in the literature. However, the pathophysiological process has been reported to include oxidative stress and inflammation in the glycerol-induced rhabdomyolysis animal model [17]. In the ATP group, CK, CK-MB, TP I, ALT, AST, LDH, BUN, creatinine, MDA, and tGSH levels were similar to the levels measured in the healthy group. In a previous study, intracellular ATP reduction was shown to be the underlying cause of rhabdomyolysis [13]. In rhabdomyolysis, an increase in myoplasmic $\mathrm{Ca}^{2+}$ concentration was found in parallel with the decrease in intracellular ATP levels [13]. An increase in intracellular $\mathrm{Ca}^{2+}$ level causes activation of intracellular proteolytic enzymes and leads to the disintegration of myocytes and the release of large amounts of potassium, aldolase, phosphate, myoglobin, CK, LDH, and AST from the cells [15]. Also, it is known that increased $\mathrm{Ca}^{2+}$ concentration leads to oxidative stress and the initiation of pathological events in the cells [16].

Kumbasar et al. [22] reported that externally provided ATP protected ischemic tissue from oxidative stress by inhibiting the overproduction of xanthine oxidase and MDA, and consumption of tGSH. However, the information on whether ATP could enter or exit the cell was not well known until a certain time. The extracellular and intracellular effects of ATP have been clarified by understanding the release of ATP as well as the uptake of cells [45]. This literature information supports our experimental results obtained by the intraperitoneal application of ATP. In another study, it was reported that injected ATP was converted to ADP, AMP, adenosine, and inorganic phosphate products, and these products entered cells and some of ADP and AMP were re-phosphorylated 
to ATP in cells [46]. In a recent study, it is understood that our idea about ATP is supported [47]. The fact that $100 \mathrm{mg} / \mathrm{kg}$ propofol administration caused more severe histopathological damage in skeletal muscle tissue compared to $50 \mathrm{mg} / \mathrm{kg}$ shows that our biochemical test results are consistent with our histopathological findings. While degeneration, muscle fiber irregularity, vascular congestion, and percutaneous nephrolithotripsy (PNL) infiltration were moderate in the animals treated with $50 \mathrm{mg} / \mathrm{kg}$ propofol, these histopathological findings were severe at a dose of 100 $\mathrm{mg} / \mathrm{kg}$. ATP significantly reduced the muscle damage induced by propofol administration at both doses. Literature data show that the spectrum and clinical significance of histopathological findings related to rhabdomyolysis remain uncertain [48]. Muscular dystrophies represent a clinically and genetically heterogeneous group of diseases characterized by progressive weakness and skeletal muscle degeneration [49]. ATP depletion, which appears to be the result of many causes of rhabdomyolysis, is associated with myocyte degeneration [9].

Prolonged use of propofol at low doses may cause muscle and tissue damage in other organs, while propofol use at higher doses may cause more severe organ and tissue damage in a shorter period. Based on the results of this study, it can be concluded that ATP better prevents muscle damage and organ dysfunction caused by $50 \mathrm{mg} / \mathrm{kg}$ propofol administration compared to the dose of $100 \mathrm{mg} / \mathrm{kg}$. These experimental results suggest that ATP may be clinically useful in the treatment of propofol-induced rhabdomyolysis and multiple organ damage.

\section{ACKNOWLEDGEMENTS}

We would like to thank the Ataturk University Medical Experimental Application and Research Center.

\section{CONFLICTS OF INTEREST}

The authors declare no conflicts of interest.

\section{REFERENCES}

1. Trevor AJ, Miller RD. General anesthetic. In: Katzung BG, editor. Basic and clinical pharmacology. 7th ed. Stamford (CT): Appleton \& Lange; 1998. p.409-423.

2. Sear JW. Toxicity of i.v. anaesthetics. Br J Anaesth. 1987;59:24-45.

3. Krajčová A, Løvsletten NG, Waldauf P, Frič V, Elkalaf M, Urban T, Anděl M, Trnka J, Thoresen GH, Duška F. Effects of propofol on cellular bioenergetics in human skeletal muscle cells. Crit Care Med. 2018;46:e206-e212.

4. Secor T, Safadi AO, Gunderson S. Propofol toxicity. In: Gunderson S, editor. StatPearls. Treasure Island (FL): StatPearls Publishing; 2020.

5. Hemphill S, McMenamin L, Bellamy MC, Hopkins PM. Propofol infusion syndrome: a structured literature review and analysis of published case reports. Br J Anaesth. 2019;122:448-459.

6. Michel-Macías C, Morales-Barquet DA, Reyes-Palomino AM, Machuca-Vaca JA, Orozco-Guillén A. Single dose of propofol causing propofol infusion syndrome in a newborn. Oxf Med Case Reports. 2018;2018:omy023.

7. Tezcan AH, Öterkuş M, Dönmez İ, Öztürk Ö, Yavuzekinci Z. A mild type propofol infusion syndrome presentation in critical care. Kafkas J Med Sci. 2018;8:61-63.

8. Tezcan AH, Ozturk O, Adali Y, Erdem E, Yagmurdur H. Abstract PR462: the effects of N-acetylcysteine in a propofol infusion syndrome model in rats. Anesth Analg. 2016;123(3 Suppl 2):586.

9. Khan FY. Rhabdomyolysis: a review of the literature. Neth J Med. 2009;67:272-283.

10. Ypsilantis P, Politou M, Mikroulis D, Lambropoulou M, Bougioukas I, Theodoridis G, Tsigalou C, Manolas C, Papadopoulos N, Bougioukas G, Simopoulos C. Attenuation of propofol tolerance conferred by remifentanil co-administration does not reduce propofol toxicity in rabbits under prolonged mechanical ventilation. J Surg Res. 2011;168:253-261.

11. Bidani A, Churchill PC. Acute renal failure. Dis Mon. 1989;35:57132.

12. Yapanoglu T, Adanur S, Ziypak T, Arslan A, Kunak CS, Alp HH, Suleyman B. The comparison of resveratrol and $\mathrm{N}$-acetylcysteine on the oxidative kidney damage caused by high dose paracetamol. Lat Am J Pharm. 2015;34:973-979.

13. Hohenegger M. Drug induced rhabdomyolysis. Curr Opin Pharmacol. 2012;12:335-339.

14. Cray SH, Robinson BH, Cox PN. Lactic acidemia and bradyarrhythmia in a child sedated with propofol. Crit Care Med. 1998;26:20872092.

15. Keltz E, Khan FY, Mann G. Rhabdomyolysis. The role of diagnostic and prognostic factors. Muscles Ligaments Tendons J. 2014;3:303312.

16. Orrenius S, Burkitt MJ, Kass GE, Dypbukt JM, Nicotera P. Calcium ions and oxidative cell injury. Ann Neurol. 1992;32 Suppl:S33-S42.

17. Gu H, Yang M, Zhao X, Zhao B, Sun X, Gao X. Pretreatment with hydrogen-rich saline reduces the damage caused by glycerolinduced rhabdomyolysis and acute kidney injury in rats. J Surg Res. 2014;188:243-249.

18. Reiter RJ. Oxidative processes and antioxidative defense mechanisms in the aging brain. FASEB J. 1995;9:526-533.

19. Park SK, Kang JY, Kim JM, Park SH, Kwon BS, Kim GH, Heo HJ. Protective effect of fucoidan extract from Ecklonia cava on hydrogen peroxide-induced neurotoxicity. J Microbiol Biotechnol. 2018;28:40-49.

20. Mathews CK, Van Holde KE, Ahern KG. Biochemistry. 3rd ed. San Francisco (CA): Addison Wesley Longman; 2000.

21. Dutka TL, Lamb GD. Effect of low cytoplasmic [ATP] on excitationcontraction coupling in fast-twitch muscle fibres of the rat.J Physiol. 2004;560(Pt 2):451-468.

22. Kumbasar S, Cetin N, Yapca OE, Sener E, Isaoglu U, Yilmaz M, Salman S, Aksoy AN, Gul MA, Suleyman H. Exogenous ATP administration prevents ischemia/reperfusion-induced oxidative stress and tissue injury by modulation of hypoxanthine metabolic pathway in rat ovary. Cienc Rural. 2014;44:1257-1263.

23. Ohkawa H, Ohishi N, Yagi K. Assay for lipid peroxides in animal 
tissues by thiobarbituric acid reaction. Anal Biochem. 1979;95:351358.

24. Sedlak J, Lindsay RH. Estimation of total, protein-bound, and nonprotein sulfhydryl groups in tissue with Ellman's reagent. Anal Biochem. 1968;25:192-205.

25. Skitek M, Kranjec I, Jerin A. Glycogen phosphorylase isoenzyme $\mathrm{BB}$, creatine kinase isoenzyme $\mathrm{MB}$ and troponin I for monitoring patients with percutaneous coronary intervention - a pilot study. Med Glas (Zenica). 2014;11:13-18.

26. Totsuka M, Nakaji S, Suzuki K, Sugawara K, Sato K. Break point of serum creatine kinase release after endurance exercise. J Appl Physiol (1985). 2002;93:1280-1286.

27. Baird MF, Graham SM, Baker JS, Bickerstaff GF. Creatine-kinaseand exercise-related muscle damage implications for muscle performance and recovery. J Nutr Metab. 2012;2012:960363.

28. Grobben RB, Nathoe HM, Januzzi JL Jr, van Kimmenade RR. Cardiac markers following cardiac surgery and percutaneous coronary intervention. Clin Lab Med. 2014;34:99-111, vii.

29. Siegel AJ, Silverman LM, Evans WJ. Elevated skeletal muscle creatine kinase $\mathrm{MB}$ isoenzyme levels in marathon runners. JAMA. 1983;250:2835-2837.

30. Ricchiuti V, Voss EM, Ney A, Odland M, Apple FS. Skeletal muscle expression of creatine kinase-B in end-stage renal disease. Clin Proteom. 2004;1:33-39.

31. Kiely PD, Bruckner FE, Nisbet JA, Daghir A. Serum skeletal troponin I in inflammatory muscle disease: relation to creatine kinase, CKMB and cardiac troponin I. Ann Rheum Dis. 2000;59:750-751.

32. Stelow EB, Johari VP, Smith SA, Crosson JT, Apple FS. Propofolassociated rhabdomyolysis with cardiac involvement in adults: chemical and anatomic findings. Clin Chem. 2000;46:577-581.

33. Alpert JS, Thygesen K, Antman E, Bassand JP. Myocardial infarction redefined--a consensus document of The Joint European Society of Cardiology/American College of Cardiology Committee for the redefinition of myocardial infarction. J Am Coll Cardiol. 2000;36:959-969.

34. Hussein A, Ahmed AA, Shouman SA, Sharawy S. Ameliorating effect of DL- $\alpha$-lipoic acid against cisplatin-induced nephrotoxicity and cardiotoxicity in experimental animals. Drug Discov Ther. 2012;6:147-156.

35. Mallard JM, Rieser TM, Peterson NW. Propofol infusion-like syndrome in a dog. Can Vet J. 2018;59:1216-1222.

36. Jo KM, Heo NY, Park SH, Moon YS, Kim TO, Park J, Choi JH, Park YE, Lee J. Serum aminotransferase level in rhabdomyolysis according to concurrent liver disease. Korean J Gastroenterol. 2019;74:205-
211.

37. Wroblewski F. The clinical significance of alterations in transaminase activities of serum and other body fluids. Adv Clin Chem. 1958;1:313-351.

38. Pratt DS. Liver chemistry and function tests. In: Feldman M, Friedman LS, Brandt LJ, editors. Sleisenger and Fordtran's gastrointestinal and liver disease. 10th ed. Philadelphia (PA): Saunders/Elsevier; 2016. p.1245-1246.

39. El-Ganainy SO, El-Mallah A, Abdallah D, Khattab MM, Mohy El-Din MM, El-Khatib AS. Elucidation of the mechanism of atorvastatin-induced myopathy in a rat model. Toxicology. 2016;359360:29-38.

40. Farswan M, Rathod SP, Upaganlawar AB, Semwal A. Protective effect of coenzyme Q10 in simvastatin and gemfibrozil induced rhabdomyolysis in rats. Indian J Exp Biol. 2005;43:845-848.

41. Dickey DT, Muldoon LL, Doolittle ND, Peterson DR, Kraemer DF, Neuwelt EA. Effect of $\mathrm{N}$-acetylcysteine route of administration on chemoprotection against cisplatin-induced toxicity in rat models. Cancer Chemother Pharmacol. 2008;62:235-241.

42. Chew DJ, Dibartola SP. Diagnosis and pathophysiology of renal disease. In: Ettinger SJ, editor. Textbook of veterinary internal medicine: Diseases of the dog and cat. 3rd ed. Philadelphia (PA): W.B. Saunders; 1989. p.1893-1961.

43. Goulart M, Batoréu MC, Rodrigues AS, Laires A, Rueff J. Lipoperoxidation products and thiol antioxidants in chromium exposed workers. Mutagenesis. 2005;20:311-315.

44. Urso ML, Clarkson PM. Oxidative stress, exercise, and antioxidant supplementation. Toxicology. 2003;189:41-54.

45. Chaudry IH. Does ATP cross the cell plasma membrane. Yale J Biol Med. 1982;55:1-10.

46. Fedelesová M, Ziegelhöffer A, Krause EG, Wollenberger A. Effect of exogenous adenosine triphosphate on the metabolic state of the excised hypothermic dog heart. Circ Res. 1969;24:617-627.

47. Hou Q, Wang Y, Fan B, Sun K, Liang J, Feng H, Jia L. Extracellular ATP affects cell viability, respiratory $\mathrm{O} 2$ uptake, and intracellular ATP production of tobacco cell suspension culture in response to hydrogen peroxide-induced oxidative stress. Biologia. 2020;75:14371443.

48. Nance JR, Mammen AL. Diagnostic evaluation of rhabdomyolysis. Muscle Nerve. 2015;51:793-810.

49. Lindberg C, Sixt C, Oldfors A. Episodes of exercise-induced dark urine and myalgia in LGMD 2I. Acta Neurol Scand. 2012;125:285287. 